\title{
Turning Crisis into Opportunity: Indonesian Chemistry Teachers' Perceptions of Socio-Scientific Issues in COVID-19
}

\author{
Ervita Eka Rosawati ${ }^{1,}$ Sri Rahayu ${ }^{2, *}$ \\ ${ }^{I}$ Master of Chemistry Education, Faculty of Mathematics and Sciences, Universitas Negeri Malang, Malang, \\ Indonesia \\ ${ }^{2}$ Department of Chemistry, Faculty of Mathematics and Sciences, Universitas Negeri Malang, Malang, \\ Indonesia \\ ${ }^{*}$ Corresponding author. Email: sri.rahayu.fmipa@um.ac.id
}

\begin{abstract}
This study examines Indonesian chemistry teachers' perceptions of socio-scientific issues (SSIs) related to COVID-19. The explored aspects include the need to introduce SSI such as COVID-19 into chemistry learning, teachers' personal efficacy beliefs regarding SSI, and the main obstacle in SSI teaching. This research was a triangulated mixed-methods design, and the data were analyzed descriptively. The 58 in-service chemistry teachers (15 males; 43 females) from 11 regions in East Java, Indonesia were chosen using a convenience sampling technique. Data were collected using a developed five-point Likert-type questionnaire. Next, a semi-structured interview was carried out with six random participants as samples. The instruments had high reliability (Cronbach's Alpha $=0.73$ ). This research reveals that participants perceived a need to introduce SSI to increase student interest. Most of them (63.8\%) agree that students need to learn and improve their decision-making skills through SSI. However, some of them (41.4\%) perceived the lack of instructional time. From the interviews, it was revealed that the unavailability of relevant material was the main obstacle in SSI teaching. Nevertheless, the teachers still wanted to develop learning materials on SSI. This study implies that further design-based research is needed by integrating individual activities into coherent instructional modules.
\end{abstract}

Keywords: Teachers' perceptions, Socio-scientific issues, Chemistry learning, COVID-19

\section{INTRODUCTION}

The emergence of the COVID-19 outbreak has caused many changes in various aspects of the world [1-6], including aspects of student life, which makes it essential to learn about COVID-19 [6]. The change also occurs in Indonesia as one of the countries affected by COVID-19, which affects educational activities at all levels [7]. COVID-19 represents a complex type of social challenge and is suitable for use as issue-based learning content [8, 9]. Issue-based learning is a form of Problem-Based Learning (PBL) which defines interesting social problems as a trigger in learning [8-10]. Socio-scientific issues present a social dilemma with a moral-ethical dimension and often arise in response to dramatic changes in some crucial aspects of human life [11]. This characteristic is in the COVID-19 pandemic, which is currently affecting almost all citizens of the world today.

Socio-scientific issues (SSIs) provide a robust framework so that it can involve students and teachers in scientific discourse that is meaningful and relevant for the development of scientific literacy [12]. The reason is that SSI takes advantage of the controversial nature and complexity of a case or phenomenon to highlight the content knowledge of science, Nature of Science (NOS), informal argumentation and reasoning, moral and ethical development, also character and values to be good citizens [12-16].

Research on SSI has expanded extensively over the past 15 years [17], but most SSI-related studies have only focused on various dimensions of student learning in terms of content knowledge, reasoning 
skills, and the Nature of Science (NOS) [18, 17]. Meanwhile, few empirical studies have focused on teachers, their perspectives on the use of SSI, and related practices on how to design or implement SSIbased teaching in the classroom [19, 20]. This statement is supported by a lot of research evidence which also shows that the SSI approach poses significant challenges for teachers [18-20].

In Indonesia, SSI-based teaching is still considered a new learning approach, so there is a need to know how teachers perceive this teaching innovation [21]. A survey on teacher perceptions of SSI-based teaching in Indonesia was conducted by Nida et al. towards science teachers, who explored their perceptions of SSI-based teaching in junior high schools [21]. Meanwhile, another research focuses more on the implementation of SSI in the classroom. This research is new because there has been no more specific survey that focuses on the perceptions of high school chemistry teachers on socio-scientific issues (SSIs) related to COVID-19. This research is essential to find out how teachers view the issue of COVID-19 in chemistry learning content so that further learning modules can be made which will offer SSI-based learning references that help students understand COVID-19.

Several studies have been conducted regarding teacher perceptions of SSI-based learning [21, 11, 15, 20]. Lee et al. investigated Korean high school science teachers' perceptions of how they introduced SSI to the science curriculum. The teachers have a favorable view of SSI even though only a few teachers have implemented SSI-based teaching in their classrooms. Besides, the teachers mentioned that the lack of time and the unavailability of supporting materials were the main difficulties that prevented them from teaching using the SSI-based approach [11].

The challenges in implementing SSI-based teaching were also raised by Bosser et al. in his research. From the findings, there is a conflict or gap between the implementation of SSI that focus on students and the achievement of learning objectives [22]. Research with the same results also occurred in Indonesia by Nida et al. that revealed that although many teachers consider SSI-based learning as a promising strategy, several obstacles need to be addressed immediately [21].

Research on SSI related to the COVID-19 was carried out by Sadler et al., in their Professional Development (PD) program for teachers on the preparation of learning materials related to the COVID-19. The results of his research revealed that some teachers expressed hesitation in handling
COVID-19 content because they were worried about the trauma that students would experience. However, according to the pediatric neurologist who was invited to the PD program, it was stated that engaging in systematic investigations and learning about facts related to trauma-inducing conditions could support students' mental health. Getting involved in this activity helps students to focus on steps they can take to protect themselves from COVID-19 [8].

Research on similar crisis phenomena, the Ebola outbreak in 2014 [9] and SARS in China in 2002 [23], shows that the crisis place science teachers in a dilemma. The teacher must decide whether to use the epidemic issue in learning or not. Besides, the lack of resources specifically designed for teachers and limited time for planning learning instruction on topics outside the curriculum are unusual demands for teachers [9]. However, the results of the study also reveal that the epidemic phenomenon can act as a practical context for teaching the understanding of Nature of Science (NOS) [23].

To better understand the extent to which chemistry teachers view and apply SSI, this research was conducted by looking deeper into their perceptions covering several aspects: (1) teachers' perceptions of the need to introduce SSI such as COVID-19 issue into chemistry learning; (2) teachers' confidence in teaching SSI, such as COVID-19 issue; and (3) teachers' perceptions of factors that hinder the use of SSI in the classroom.

\section{RESEARCH METHODS}

\subsection{Participants}

This study was designed using a mixed-method triangulation. The research questionnaire was distributed virtually via Google Form to chemistry teachers in East Java. A total of 58 chemistry teachers from high schools volunteered to fill out the questionnaire. After that, semi-structured interviews were conducted with selected teachers from the samples. After the initial screening of the questionnaire, six teachers were selected based on variations in their data and answers. Interviews were conducted two weeks after filling out the questionnaire to deepen the findings.

The 58 participating teachers work in different schools and have different educational backgrounds. A total of 36 teachers teach in public high schools, the others work in the private school, and two teachers do not specify any affiliation. Details of educational 
background, type of affiliate, and teaching experience are given in Table 1.

\subsection{Questionnaire}

The questionnaire consists of 15 five-point Likerttype items. It aims to find out chemistry teachers' Table 1. Background of participants $(\mathrm{N}=58)$ perceptions of socio-scientific issues related to COVID-19 in learning. The questionnaire provides descriptions and examples of SSI passages related to the issue of COVID-19 to provide a comprehensive definition of what SSI is.

\begin{tabular}{|c|c|c|}
\hline Aspect & Profile & Total \\
\hline \multirow[t]{2}{*}{ Gender } & Male & 15 \\
\hline & Female & 43 \\
\hline \multirow[t]{8}{*}{ Educational Background } & \multicolumn{2}{|l|}{ Bachelor's Degree in: } \\
\hline & Chemistry Education & 36 \\
\hline & Chemistry & 6 \\
\hline & Others (Physics Education) & 1 \\
\hline & \multicolumn{2}{|l|}{ Master's Degree in: } \\
\hline & Chemistry Education & 10 \\
\hline & Chemistry & 4 \\
\hline & Others (Management) & 1 \\
\hline \multirow[t]{3}{*}{ Type of school } & Public high school & 36 \\
\hline & Private high school & 20 \\
\hline & No affiliation & 2 \\
\hline \multirow[t]{5}{*}{ Teaching experience } & $0-5$ years & 19 \\
\hline & $6-10$ years & 9 \\
\hline & $11-15$ years & 8 \\
\hline & $16-20$ years & 9 \\
\hline & More than 20 years & 13 \\
\hline
\end{tabular}

SSI is defined as a social issue that is conceptually connected to science, which has characteristics, among others, creates controversy/dilemma/pros and cons in society, can be debated, relates to science/technology, and requires both scientific, ethical, moral and social considerations. From the descriptions and examples of SSI passages, it is assumed that the participants get the same opinion about SSI.

All Likert-type items were adapted from an instrument developed by Lee [11] concerning science teachers' perceptions of the introduction of socioscientific issues into the science curriculum. The researcher then made several changes to suit the conditions in Indonesia. Likert-type items in this study targeted three domains and had moderate to high reliability (as shown by Cronbach's alpha). The three domains are: (a) teachers' perceptions of the need to introduce SSI with examples of COVID-19 issues into chemistry learning (5 items, $\alpha=0.55$ ); (b) teachers' confidence in teaching SSI, such as COVID-19 issues (5 items, $\alpha=0.58$ ); and (c) teachers' perceptions of factors that hinder the use of SSI in the classroom (5 items, $\alpha=0.72$ ).

\subsection{Semi-structured Interviews}

After giving the questionnaire, researchers conducted semi-structured interviews with a randomly selected sample of 6 participants $(10.3 \%)$. From overall interviewed participants, three participants were females $(50 \%)$; two participants had less than five years of teaching experience, two participants had teaching experience between 6 and 15 years, and two other participants had teaching experience of more than 20 years. The interview aims to explore chemistry teachers' perceptions of socio-scientific issues related to COVID-19 in more in-depth learning and to provide 
further insight into teacher perceptions. The researcher developed all questions in the semi-structured interview according to the Likert type item in the questionnaire. The interview was guided by a series of questions, including: (1) the teachers' views on science, especially chemistry; (2) teachers' experiences in chemistry teaching and learning; (3) participants' perceptions regarding experiences with SSI and the issue of COVID-19 in chemistry learning. Furthermore, follow-up questions, probing questions, and general clarification were used during the interview process. The interviews lasted between 15 and 30 minutes. All interviews were recorded and transcribed verbatim for analysis.

\subsection{Data Analysis}

Questionnaire data were analyzed using descriptive statistics. Meanwhile, responses to semistructured interview questions were recorded, read, coded, and analyzed for themes and categories related to teachers' perceptions of SSI and the COVID-19

Table 2. Chemistry teachers' perceptions of the need to introduce SSI with examples of COVID-19 issue into chemistry learning ${ }^{\mathrm{a}}$

\begin{tabular}{|c|c|c|c|c|c|c|}
\hline \multirow[t]{2}{*}{ No } & \multirow[t]{2}{*}{ Item } & \multicolumn{5}{|c|}{ Percentage (\%) } \\
\hline & & SA & A & $\mathrm{N}$ & D & SD \\
\hline 1 & $\begin{array}{l}\text { If I can get material on socio-scientific issues, } \\
\text { such as issues COVID-19, so I would like to } \\
\text { develop materials on socio-scientific issues for } \\
\text { learning chemistry in the classroom }\end{array}$ & 58.6 & 36.2 & 5.2 & 0 & 0 \\
\hline 4 & $\begin{array}{l}\text { I am willing to participate in training programs on } \\
\text { the application of socio-scientific issues, such as } \\
\text { COVID-19 issues, in chemistry learning }\end{array}$ & 46.6 & 46.6 & 6.8 & 0 & 0 \\
\hline 6 & $\begin{array}{l}\text { I think it is more appropriate to use socio- } \\
\text { scientific issues, such as COVID-19 issues, in } \\
\text { learning ethics, sociology, or technology than in } \\
\text { science learning }(\mathrm{Neg})^{\mathrm{b}}\end{array}$ & 8.6 & 10.3 & 12.1 & 62.1 & 6.9 \\
\hline 8 & $\begin{array}{l}\text { In my opinion, introducing socio-scientific issues, } \\
\text { such as COVID-19 issues into chemistry learning } \\
\text { is necessary to increase student interest }\end{array}$ & 39.7 & 60.3 & 0 & 0 & 0 \\
\hline 15 & $\begin{array}{l}\text { Students need to learn and improve their ability } \\
\text { to make decisions on issues socio-scientific in } \\
\text { chemistry learning, such as issues COVID-19 }\end{array}$ & 34.5 & 63.8 & 1.7 & 0 & 0 \\
\hline
\end{tabular}

issue. Initial themes and categories were examined from the data and modified accordingly. Categorization and confirmation were carried out several times to narrow and organize the data satisfactorily [24]. The questionnaire data analysis was then illustrated and enriched with responses from the interviews.

\section{RESULT}

\subsection{Teachers' Perceptions of the Need to Introduce SSI with Examples of COVID-19 Issue into Chemistry Learning}

Several questionnaire items were used to find out the perception of chemistry teachers about the need to introduce SSI with examples of COVID-19 issue in learning, as in Table 2. A total of $60.3 \%$ of teachers stated that introducing socio-scientific issues, such as 
COVID-19 issues, into chemistry learning needs to be done to increase students' interest. The results of the interview also revealed that the participants admitted that introducing socio-scientific issues in learning had several advantages, including sharpening students' critical thinking and problem-solving skills, increasing students' interest and motivation to learn, and students becoming more sensitive to the environment and having broader insights. As expressed by R2, "The advantage is that children are more interested in learning, their interest is high because they know the material is related to everyday life, they also can explain the phenomenon."

The majority of participants stated that they strongly agreed to develop material on socio-scientific issues in chemistry learning in the classroom, if they could get material on socio-scientific issues, such as COVID-19 (58.6\%). Almost all participants (93.2\%) were willing to participate in training programs on the implementation of socio-scientific issues, such as COVID-19 issues, in chemistry learning. Unexpectedly, more than half of the participants have a favorable view of socio-scientific issues, $62.1 \%$ of participants stated that they disagreed and thought socio-scientific issues such as COVID-19 issues would be more appropriate to use in learning ethics, sociology, or technology than in science learning. These teachers believe that students need to learn and improve their ability to make decisions about socioscientific issues in chemistry learning (63.8\%).

The findings of the data are linear with the results of the interviews. All participants admitted that they had introduced socio-scientific issues in chemistry learning, but the intensity and scope of their use were not too frequent and widespread in every learning topic. They mentioned several issues related to reallife aspects of chemistry. R2 argued:

It was introduced several times during the lesson, usually on issues that have a broad impact, as I mentioned earlier, global warming. The rest, for issues that are not too prominent, I usually only mention them at the beginning of the lesson about their relationship to the material and its relation to everyday life (R2).

Not far from R2's opinion, R6 revealed another example of socio-scientific issues that he had used in chemistry studies. "Of course, there are, and a lot. For example, water or environmental pollution caused by factory waste that is disposed of carelessly and treated improperly."

All the participants agreed that the issues they had previously mentioned or other similar issues were potential for use in chemistry learning. Several participants mentioned similar issues that have the potential to be used in learning chemistry. R1 stated that the issue must be the latest, and he gave an example of health, environmental, and industrial issues. "Of course, it is very potential, especially regarding current issues, for example, related to health, industry, the environment, we can relate it to chemistry learning." R2 provides another example, "...there are many issues in society that we can raise in learning, for example, about energy, global warming, environmental damage, and others."

Regarding COVID-19 issue, all participants agreed that the topic of COVID-19 was necessary and urgent in a pandemic like today. As R1 says:

It is essential because a pandemic is currently taking place in this country. So, it is about how competent the teacher to teach and provide information to students, how to prevent it, what selfprotection is necessary, and what to do. For example, in chemistry subjects with experiment making hand sanitizers or soap. In other subjects, it must also be the same because the impact of COVID-19 is not only in the science field but also in other fields, such as economics and society $(R 1)$.

All participants stated that topics related to COVID-19 could be used in learning. However, one participant, R3 stated that the topic does not need to be linked to learning, it is enough to give an appeal about it, "I think it is necessary always to urge students to maintain health and discipline to prevent COVID-19, but if it is integrated into learning, I think no need". Some said that it is difficult to apply in chemistry, easier if it is in biology. Only partially can associated it with chemistry materials. As stated by the R5, "It can be and is possible. In chemistry, maybe we still need to investigate further, but in biology, it belongs to the topic of the virus."

In contrast to R5's opinion, R2 has other ideas regarding the use of the topic of COVID-19 in chemistry learning:

It is possible. One of them is hand sanitizer. This means that if we include the issue of hand sanitizer, it will belong to the solubility material in eleventh grade. If you wash your hands with soap, it is in colloidal material. Then regarding the structure of RNA virus, it belongs to polymer material in twelfth grade, or tenth-grade material about atoms, you can analyze what atoms make up the virus (R2). 


\subsection{Teachers' Confidence in Teaching SSI about COVID-19}

The majority of chemistry teachers show a positive perception of the need to introduce SSI in chemistry learning. The results of questionnaire data from the five Likert items in this category show linearity that the teacher had pretty high confidence in teaching SSI (as shown in Table 3 ). They $(58.6 \%)$ expressed a sufficient understanding of socio-scientific issues in science and technology; $53.4 \%$ have confidence in developing learning materials about socio-scientific issues, such as COVID-19 issues. The results of the questionnaire data on other items also revealed that $50 \%$ of teachers claimed to have the knowledge needed to teach socio-scientific issues, such as COVID-19 issues to their students effectively. Indeed, $55.2 \%$ stated that they could apply various teaching strategies when using socio-scientific issues in the classroom. This data is supported by $41.4 \%$ of teachers who disagree with the assumption that using socioscientific issues, using various teaching strategies (role-plays and group activities) is almost impossible to do in real classroom situations.

Unfortunately, the results of the questionnaire data and the interviews conducted revealed a gap between teachers' confidence in teaching SSI and their genuine commitment to teaching about this issue in their class. All participants stated that they occasionally discuss SSI in their class, even though they have little experience with it. On further investigation of the data through questions during the interview, a clearer picture emerged. Some participants did not teach SSI systematically, they also do not spend much time giving students opportunities or guidance in thinking about the problem. On the contrary, as was evident during the individual interviews, they seemed to either ignore SSI very briefly or dedicate a few minutes during the lesson to merely brooding the issue with the material.

As stated by R1:

For learning about colloid, just do it with videos and experiments. For radiochemistry, in face-to-face learning, I usually prepare a picture or video in advance, for example about a bomb, meaning we prepare a bomb incident first, then we discuss what materials cause a bomb to react in that way can be explained through pictures or PowerPoint because most students are interested in audio-visuals. We can also attract students to find their references through YouTube (Rl).

Table 3. Chemistry teachers' confidence in teaching SSI, such as COVID-19 issues

\begin{tabular}{|c|c|c|c|c|c|c|}
\hline \multirow[t]{2}{*}{ No } & \multirow[t]{2}{*}{ Item } & \multicolumn{5}{|c|}{ Percentage (\%) } \\
\hline & & SA & A & $\mathrm{N}$ & D & SD \\
\hline 3 & $\begin{array}{l}\text { I can apply various teaching strategies when using } \\
\text { socio-scientific issues, such as COVID-19 issues in } \\
\text { the classroom. }\end{array}$ & 25.9 & 55.2 & 18.9 & 0 & 0 \\
\hline 10 & $\begin{array}{l}\text { I understand quite well about socio-scientific issues, } \\
\text { such as the issues of COVID-19, in science and } \\
\text { technology }\end{array}$ & 8.6 & 58.6 & 25.9 & 6.9 & 0 \\
\hline 12 & $\begin{array}{l}\text { I have confidence in developing learning materials } \\
\text { on socio-scientific issues, such as COVID-19 issues }\end{array}$ & 17.2 & 53.4 & 27.6 & 1.8 & 0 \\
\hline 13 & $\begin{array}{l}\text { Using socio-scientific issues, such as COVID-19 } \\
\text { issues, with various teaching strategies (role-plays } \\
\text { and group activities) is almost impossible to do in } \\
\text { real classroom situations (Neg)b }\end{array}$ & 3.4 & 27.6 & 24.1 & 41.4 & 3.5 \\
\hline 14 & $\begin{array}{l}\text { I know necessary to teach socio-scientific issues, } \\
\text { such as issues COVID-19 effectively to my students }\end{array}$ & 10.3 & 50.0 & 25.9 & 12.1 & 1.7 \\
\hline
\end{tabular}

${ }^{\mathrm{a}} \mathrm{SA}=$ Strongly Agree; $\mathrm{A}$ = Agree; $\mathrm{N}$ = Neutral; D = Disagree; $\mathrm{SD}$ = Strongly Disagree

${ }^{\mathrm{b}}$ The item that is followed by $\mathrm{Neg}$ is a negative statement

Likewise, as explained by R4:

The easiest way is by video, but it would be nice if it is delivered by giving direct experience to students. 
For example, when learning about acids and bases (natural indicators), we can teach students to tour around the school by bringing some samples of acid and alkaline solutions. Then we test them using several plants around the school which can be used as natural indicators (R4).

Even $\mathrm{R} 3$ revealed that students were independently assigned to look for references in online media, without explaining further about that. "Usually, students look for relevant references online, then we discuss them in class." The explanation from the three participants indicates the use of SSI that are less indepth and have not been taught instructional. Participants consider that SSI is just a phenomenon in everyday life related to science, without realizing the characteristics of SSI, including causing controversy/dilemma/pros and cons in society, can be debated, related to science/technology, and requires scientific, ethical, moral and social considerations.

In contrast to this, other participants showed little progress in terms of teaching topics using SSI, although not yet fully structured. R2 gives an example in the material the reaction rate, which can explain the global warming phenomenon.

First, I think that ideally students already know this phenomenon. I assume that students already know what the ozone layer is. If they are still confused about what the ozone layer is, I ask them to browse and find references. From this explanation, there must be an issue about the depletion of the ozone layer, from that I then pulled it to the statement "how can scientists predict when the ozone layer will run out?" So, from that, then we connect to the concept of reaction rate. So I linked the phenomena in the reference to the learning topic (R2).

R5 and R6 give a better explanation:

I instruct students directly to go into the surrounding environment to make observations, for example, by going to a shopping center to record the content or composition in daily necessities products. The next, I linked it to the existing issues, for example, using MSG, which is still the pros and cons, and continued with class discussions (R5).
First, I raised an environmental issue related to the impact of industrial waste (oil) on the environment. My students asked me to discuss determining why oil has a destructive impact on the environment, what its composition is, and whether its processing methods good or bad. Then, I got into the material of petroleum. They can use videos, search for references on the internet, or even through printed media by making clippings (R6).

Regarding the selection of relevant SSI context, the interview results reveal more profound findings than the questionnaire data. Almost all of the participants admitted that they still had difficulty choosing the relevant context. Most rely on online media as a source of relevant and up to date references. Some look for the issue first then link it with the appropriate material, and some review the material first, what material has issues that are currently developing in society.

$\mathrm{R} 3$ revealed, "Yes, the difficulty is at that point. If there is a material that matches the issue, then I use it in learning. However, if there is not, I use an event that is booming, then I will discuss it. Sometimes, it is students who bring problems into the classroom, so that we can discuss them". R6 also expressed the same thing, "These are still many obstacles. I prefer to search for online media, such as trusted global news, then we study what topics can explain the issue."

\subsection{Teachers' Perceptions of the Factors that Hinder the Use of SSI in the Classroom}

Apart from the perception of chemistry teachers on the need to introduce SSI in chemistry learning from the data previously described, the results of the questionnaire and interview data reveal that there are factors that hinder the use of SSI in the classroom. It can be seen from the results of the questionnaire data in Table 4 , which states that $32.8 \%$ of teachers agree that the limited learning time makes them feel burdened in learning. According to the teachers, the factors originating from students do not hinder the use of SSI in the classroom.

Table 4. Teachers' perceptions of factors that hinder the use of SSI in class ${ }^{\mathrm{a}}$

\begin{tabular}{|c|l|c|c|c|c|c|}
\hline \multirow{2}{*}{ No } & \multicolumn{2}{|c|}{ Item } & \multicolumn{5}{c|}{ Percentage (\%) } \\
\cline { 3 - 7 } & \multicolumn{1}{|c|}{ SA } & A & N & D & SD \\
\hline 2 & $\begin{array}{l}\text { Limited class time makes me feel burdened } \\
\text { when dealing with socio-scientific issues, } \\
\text { such as COVID-19 issues, in learning (Neg) }\end{array}$ & 8.5 & 32.8 & 12.1 & 41.4 & 5.2 \\
& & & & & & \\
\hline
\end{tabular}




\begin{tabular}{|c|c|c|c|c|c|c|}
\hline \multirow[t]{2}{*}{ No } & \multirow[t]{2}{*}{ Item } & \multicolumn{5}{|c|}{ Percentage (\%) } \\
\hline & & SA & A & $\mathrm{N}$ & D & SD \\
\hline 5 & $\begin{array}{l}\text { I believe that students are not mature } \\
\text { enough to be interested in and understand } \\
\text { socio-scientific issues ( } \mathrm{Neg} \text { ) }\end{array}$ & 6.9 & 34.5 & 15.5 & 37.9 & 5.2 \\
\hline 7 & $\begin{array}{l}\text { I believe that students have almost no } \\
\text { interest in socio-scientific issues or COVID-19 } \\
\text { issues (Neg) }\end{array}$ & 1.8 & 12.1 & 17.2 & 60.3 & 8.6 \\
\hline 9 & $\begin{array}{l}\text { Related learning with socio-scientific issues } \\
\text { such as COVID-19 issues are more likely to } \\
\text { be applied to students who have high } \\
\text { learning achievement (Neg) }\end{array}$ & 6.9 & 24.1 & 12.1 & 50.0 & 6.9 \\
\hline 11 & $\begin{array}{l}\text { I believe that chemistry learning addresses } \\
\text { socio-scientific issues, such as the issues of } \\
\text { COVID-19, had little effect on the } \\
\text { achievement of students with low motivation } \\
\text { (or low-level of participation) } \\
\text { ( Neg) }\end{array}$ & 1.8 & 10.3 & 20.7 & 60.3 & 6.9 \\
\hline
\end{tabular}

${ }^{\mathrm{a}} \mathrm{SA}=$ Strongly Agree; A = Agree; $\mathrm{N}$ = Neutral; D = Disagree; $\mathrm{SD}$ = Strongly Disagree

${ }^{\mathrm{b}}$ The item that is followed by Neg is a negative statement

According to the teachers, the factors originating from students do not hinder the use of SSI in the classroom. $60.3 \%$ of teachers expressed their disapproval if students were deemed not to have an interest in socio-scientific issues, such as COVID-19 issues. However, the result is quite a dilemma occurs in the assumption that students are not mature enough to be involved and interested in SSI, $37.9 \%$ of teachers disagreed with the statement, but $34.5 \%$ stated the opposite. Even so, $50 \%$ of teachers disagree with the assumption that learning related to socio-scientific issues such as COVID-19 issues is more likely to be applied to students who have high learning achievement and only have a small effect on the achievement of students with low motivation (or lowlevel of participation) (60.3\%).

Participant responses in semi-structured interviews clarify the results of questionnaire data about factors that hinder the use of SSI in the classroom. In more detail, they revealed several problems in using SSI in chemistry learning: (a) limited facilities from schools; (b) limited time (both allocation of learning and time to prepare teaching materials); (c) limited sources of relevant references, and (d) administrative duties and competency demands that must be completed. R1 revealed:
The obstacles were not too much there, but maybe only the facilities from the school were inadequate. Sometimes we are ready, but the facilities from the school turn out to be short, and we have to share with other teachers. Sometimes the students are not ready either, in terms of the use of information technology. It looks small, but it also affects the delivery of learning (R1).

In contrast to R1, R2 said, "As I told you earlier, maybe the problem is in the time allocation which is still limited by the competencies that must be completed, especially on the material that is in the national examination."

As for R6, it raises another factor:

The obstacle for me to date is the lack of relevant reference sources. Because we know for ourselves at this time, when we only focus on textbooks, of course, we will not get anything, maybe the learning objectives will be achieved, but beyond that, things like these socio-scientific issues will not possibly be implemented. If the media is online, of course, we have to explore it first, do not let it contain hoaxes or racial intolerance (R6).

Regarding the obstacles that come from students, only one participant expressed it, R5 said: 
For me, it is the condition of students who need more preparation to take part in learning with socioscientific issues. Because sometimes students have to be more open and vocal so that the discussion becomes more active. Of course, this requires repeated practice on the part of the teacher himself how to manage the class well (R5).

\section{DISCUSSION}

Chemistry teachers who participated in this study had a positive perception of the use of socio-scientific issues (SSIs), including the issue of COVID-19 in learning. Most of the participants believed that such issues or other similar issues could be used in learning chemistry because of the many benefits students could get from learning with SSI. Participants also stated that they have sufficient confidence to use SSI in their class. However, from the results of more in-depth interviews, participants did not dedicate much time to using SSI in their classroom nor did they teaching it more systematically. They mention some of the strategies used, such as making declarative statements or asking rhetorical questions about the issues raised and focus more on discussing the chemical content required by the curriculum or as a means to grab students' attention when discussing that content.

Similar research results also appear to have occurred in the study conducted by Lee et al. [11] and Jenkins [25]. Lee's study of Korean science teachers' perceptions of the introduction of socio-scientific issues into the science curriculum, revealed that science teachers in Korea use SSI only on the surface and do not teach it systematically [11]. In these studies, teachers' beliefs about curricular priorities (e.g. priorities for completing curriculum competencies) are one of the most critical factors leading to lower self-confidence in teaching [11, 2628]. As Jenkins [25] points out about SSI-related material "for the most part ... lacks a sufficient theoretical basis and serves a limited function ... to support and enrich conventional science learning."

The implementation of the SSI-based approach is still limited, even in Western countries, because many teachers still see the main objective of science learning as the delivery of scientific facts and theories [29]. In Indonesia itself, SSI-based approaches do not appear to have been widely developed and have had only limited influence on curriculum reform in science education [21]. Research by Nida et al. [21] revealed, although the teachers viewed SSI-based learning positively and saw its potential for character building; the participants did not show a high level of implementation of SSI-based learning in their class. It is suggested that teachers should be given more resources and provided comprehensive support to overcome the difficulties faced in implementing SSIbased learning [29, 30]. This support needs to be provided by the government, curriculum developers, and science education researchers so that teachers can overcome any problems they face in implementing SSI-based pedagogy in the classroom.

This study identified several factors that appear to hinder the use of SSI in chemistry learning. Lack of relevant teaching or reference materials, lack of time to plan and prepare materials and teach SSI, and the difficulties associated with implementing a practical instructional approach for students are some of the actionable barriers. It can be overcome by offering some practical recommendations to empower teachers to act on their perceptions and to use SSI meaningfully in their classrooms. In this regard, there is an immediate need to develop module teaching materials related to SSI teaching in a more structured and systematic manner. As can be seen from the results of this study, participants do not yet have in-depth knowledge or understanding of the content and instructional approach needed to use SSI effectively. They expressed a lack of time or resources in developing the material. In order to create structural instructional materials is not only following the needs of teachers, but also the students in which become the essential part.

Another factor that hinders the teaching of SSI in the classroom is a factor related to the teachers themselves. An integrated and continuous professional development program is needed to help teachers acquire content knowledge, develop pedagogical skills, and internalize the attitudes and habits of mind necessary for effective teaching with SSI [11]. Participants in this study recognized many competencies and skills that could be developed using SSI-based teaching and learning processes. This applies to both students and teachers. Teachers acknowledge SSI's connection to the lives of their students and society. They view SSI as a way to help students, including students with low achievement, become more involved in discussions, developed critical thinking and problem-solving skills. This is consistent with what Zeidler et al. stated that SSI pedagogy transcends traditional teaching practices by encouraging students to highlight multi-perceptual factors such as interpreting problems, making decisions, solving problems, and engaging in argumentation [31].

The introduction and use of the COVID-19 issue in chemistry learning were still new to participants. In 
the context of issues related to COVID-19, it is necessary to make various innovations in terms of developing teaching materials related to these issues. These innovations can be in the form of innovative programs created by students [7]. The development of the 21 st-century requires creativity and the ability to provide original, innovative ideas according to 21 stcentury learning [32 - 35]. Topics related to the issue of COVID-19 in several recent studies are essential to criticize problems and solve problems $[6,7]$. Students are not only asked to be critical and solve problems but also asked to have innovative programs to solve various problems, and in this case, the COVID-19 problem [6].

The use of socio-scientific issues about outbreaks in learning has been studied by Wong et al. [23] regarding the SARS outbreak. His research findings suggest that endemic problems for students can often be used to deliver SSI place-based instructions that meet pedagogical objectives. The study looked at the SARS outbreak that students experienced in their local community to help them learn about NOS and the original work of epidemiologists [36].

Teachers in compiling teaching materials related to the COVID-19 issue are expected to be able to innovate so that students are willing to comply with various policies on using masks, washing hands with soap, and physical distance. This joint effort is essential because to solve various problems, it requires active efforts simultaneously and not only by individuals [37 - 43]. For further research related to the preparation of teaching materials on the issue of COVID-19, innovation is needed in learning media, learning strategies, learning models, teaching materials, and student worksheets. Innovations like these are also necessary to support 21 st-century learning [42 - 45].

The findings in this study regarding chemistry teachers' perceptions of the use of socio-scientific issues such as the COVID-19 issue in learning, contribute to what follow-up research is needed. The results of other studies show that students' HOTS in the context of COVID-19 is still very low. Previous research has recommended the development of various learning instruments, one of which is in the form of a digital worksheet related to COVID-19 [6, 8]. Contextual learning will be easier for students to understand, 6compared to learning with irrelevant topics [33, 39, 46 - 53].

Studying innovations in e-learning during COVID19 becomes necessary. Teachers also have to anticipate various obstacles that may occur during elearning [56]. Therefore, a professional development program is needed for teachers to develop their teaching materials and skills related to the use of the COVID-19 issue in learning during this pandemic. Such a program has been conducted by Sadler et al. [8] on a limited group of teachers online. From the results of similar research, it is recommended to continue the design-based research process, which leads to the creation of COVID-19 teaching materials, by integrating individual activities into a coherent instructional module. This module will offer a problem-based learning platform that helps students understand COVID-19.

\section{CONCLUSION}

More than half the number of teachers in this study stated the need to introduce socio-scientific issues, such as COVID-19 issues into chemistry learning. They agree that students need to learn and improve their ability to make decisions through SSI. However, in practice, participants revealed the main obstacles they face when using SSI in class, including limited facilities from schools, limited time (both allocation of learning and time to prepare teaching materials), limited sources of relevant references, and demands for school administration tasks. Despite the many challenges, all teachers stated that they wanted to develop learning materials about SSI. This study implies that there is a need to conduct further research to develop a coherent SSI-based learning module and conduct teacher professional development programs related to the use of the COVID-19 issue in learning.

\section{ACKNOWLEDGMENTS}

Financial support for this research from Indonesia Endowment Fund for Education, Ministry of Finance Republic Indonesia (LPDP, Kementerian Keuangan $R I)$ is gratefully acknowledged.

\section{REFERENCES}

[1] X.B. Pan, Application of Personal-Oriented Digital Technology in Preventing Transmission of COVID-19, Irish Journal of Medical Science 189(1) (2020)1 145-1146. DOI: https://doi.org/10.1007/s11845-020-02215-5

[2] Y. Wang, Y. Di, J. Ye, W. Wei, Study on The Public Psychological States and its Related Factors During The Outbreak of Coronavirus Disease 2019 (COVID-19) in Some Regions of China, Psychology, Health \& Medicine 26(1) (2020) 1-10. DOI: https://doi.org/10.1080/13548506.2020.1746817 
[3] B. Salzberger, T. Glück, B. Ehrenstein, Successful Containment of COVID-19: The WHO-Report on The COVID-19 Outbreak in China, Journal of Infection 48(2) (2020) 151153. DOI: https://doi.org/10.1007/s15010-02001409-4

[4] G. Zhou, S. Chen, Z. Chen, Back to The Spring of Wuhan: Facts and Hope of COVID-19 Outbreak, Frontiers of Medicine 14(2) (2020) 113-116. DOI: https://doi.org/10.1007/s11684020-0758-9

[5] S. Tian, N. Hu, J. Lou, K. Chen, X. Kang, Z. Xiang, J. Zhang, Characteristics of COVID-19 Infection in Beijing, Journal of Infection 80(4) (2020) 401-406. DOI: https://doi.org/10.1016/j.jinf.2020.02.018

[6] I.Z. Ichsan, H. Rahmayanti, A. Purwanto, D.V. Sigit, C-S. Singh, R-M. Babu, HOTS-AEPCOVID-19: Students Knowledge and Digital Worksheet of ILMIZI Environmental Learning Model, International Journal of Advance Science and Technology 29(2) (2020) 5231-5241. DOI: https://doi.org/10.22219/jpbi.v6i2.12161

[7] I.Z. Ichsan, H. Rahmayanti, HOTSEP: Revised Anderson's Taxonomy in Environmental Learning of COVID-19, European Journal of Educational Research 9(3) (2020) 1257-1265. DOI: https://doi.org/10.12973/eu-jer.9.3.1257

[8] T.D. Sadler, P. Friedrichsen, L. Zangori, L. Ke, Technology Supported Professional Development for Collaborative Design of COVID-19 Instructional Materials, Journal of Technology and Teacher Education 28(2) (2020) 171-177.

[9] P.S. Smith, J.A Torsiglieri, R.K. Esch, J.D. Pasley, When 'We Wish They Knew' Meets 'I Want to Know', International Journal of Science Education 39(13) (2017) 1830-1845. DOI: https://doi.org/10.1080/09500693.2017.1353714

[10] R. Marra, D.H. Jonassen, B. Palmer, S. Luft, Why Problem-Based Learning Works: Theoretical Foundations, Journal Excellence in College Teaching 25(3) (2014) 221-238.

[11] H. Lee, F. Abd-El-Khalick, K. Choi, Korean Science Teachers' Perceptions of The Introduction of Socio-Scientific Issues Into The Science Curriculum, Canadian Journal of Science, Mathematics, Technology, and
Education 6(2) (2006) 97-117. DOI: https://doi.org/10.1080/14926150609556691

[12] A.Z. Macalag, J. Johnson, M. Lai, How Do We Do This: Learning How to Teach Socio-Scientific Issues, Cultural Studies of Science Education 15(2) (2020) 389-413. DOI: https://doi.org/10.1007/s11422-019-09944-9

[13] M.L. Klosterman, T.D. Sadler, Multi-Level Assessment of Scientific Content Knowledge Gains Associated with Socio-Scientific Issuesbased Instruction, International Journal of Science Education 32(8) (2010) 1017-1043. DOI:

https://doi.org/10.1080/09500690902894512

[14] J.L. Eastwood, T.D. Sadler, D.L. Zeidler, A. Lewis, L. Amiri, S. Applebaum, Contextualizing Nature of Science Instruction in Socio-Scientific Issues, International Journal of Science Education 34(15) (2012) 2289-2315. DOI: https://doi.org/10.1080/09500693.2012.667582

[15] M.S. Topcu, T.D. Sadler, O. Y. Tuzun, Preservice Science Teachers' Informal Reasoning about Socio-Scientific Issues: The Influence of Issue Context, International Journal of Science Education 32(18) (2010) 2475-2495. DOI: https://doi.org/10.1080/09500690903524779

[16] T. Tal, Y. Kedmi, Teaching Socio-Scientific Issues: Classroom Culture and Students' Performances, Cultural Studies of Science Education 1(2) (2006) 615-644. DOI: https://doi.org/10.1007/s1142 2-006-9026-9

[17] D.L. Zeidler, Handbook of Research on Science Education, Routledge, 2014.

[18] K. Li, T.D. Sadler, L. Zangori, P.J. Friedrichsen, Students' Perceptions of Socio-Scientific IssueBased Learning and Their Appropriation of Epistemic Tools for Systems Thinking, International Journal of Science Education 42(8) (2020) 1-23. DOI: https://doi.org/10.1007/s11422-006-9026-9

[19] T.S. Hancock, P.J. Friedrichsen, A.T. Kinslow, T.D. Sadler, Selecting Socio-Scientific Issues for Teaching, Science \& Education 28(3) (2019) 639-667. DOI: https://doi.org/10.1007/s11191019-00065-X

[20] M. Ekborg, C. Ottander, E. Silfver, S. Simon, Teachers' Experience of Working with SocioScientific: A Large Scale and in-Depth Study, Research in Science Education 43(1) (2013) 599- 
617. DOI: https://doi.org/10.1007/s11165-011$\underline{9279-5}$

[21] S. Nida, S. Rahayu, I. Eilks, A Survey of Indonesian Science Teachers' Experience and Perceptions toward Socio-Scientific IssuesBased Science Education, Education Sciences 10(2) $2020 \quad 1-15 . \quad$ DOI: https://doi.org/10.3390/educsci10020039

[22] U. Bossér, M. Lundin, M. Lindahl, Challenges Faced by Teachers Implementing SocioScientific Issues as Core Elements in Their Classroom Practices, European Journal of Science and Mathematics Education 3(2) (2015) 159-176.

DOI: https://doi.org/10.30935/scimath/9429

[23] S.L. Wong, D. Hodson, J. Kwan, B.H.W. Yung, Turning Crisis into Opportunity: Enhancing Student-Teachers' Understanding of Nature of Science and Scientific Inquiry through A Case Study of The Scientific Research in Severe Acute Respiratory Syndrome, International Journal of Science Education 30(11) (2008) 1417-1439. DOI:

https://doi.org/10.1080/09500690701528808

[24] M.D. LeCompte, J. Preissle, Ethnography and Qualitative Design in Educational Research, Academic Press, 1993.

[25] E.W. Jenkins, Linking School Science Education with Action, Peter Lang, 2002.

[26] L.K. Ramey-Gassert, M.G. Shroyer, Enhancing Science Teaching Self-Efficacy in Preservice Elementary Teachers, Journal of Elementary Science Education 4(1) (1992) 26-34. DOI: https://doi.org/10.1007/BF03173752

[27] I.M. Riggs, L.G. Enochs, Toward The Development of An Elementary Teacher's Science Teaching Efficacy Belief Instrument, Sciences Education 74(6) (1990) 625-637. DOI: https://doi.org/10.1002/sce.3730740605

[28] P.T. Ashton, Teacher Efficacy: A Motivational Paradigm for Effective Teacher Education, Journal of Teacher Education 35(5) (1984) 28-32. DOI:

https://doi.org/10.1177/002248718403500507

[29] T.D. Sadler, Socio-Scientific Issues in The Classroom: Teaching, Learning and Research, Springer, 2011
[30] R. M. Naaman, I. Eilks, G. Bodner, A. Hofstein, Professional Development of Chemistry Teachers: Theory and Practice, RSC Publishing, 2018.

[31] D.L. Zeidler, T.D. Sadler, Argumentation in Science Education: Perspectives from Classroom Based Research, Springer, 2007.

[32] M. Deschryver, Using The Web as A Higher Order Thinking Partner: Case Study of An Advanced Learner Creatively Synthesizing Knowledge on The Web, Journal of Educational Computing Research 55(2) (2017) 240-227. DOI:

https://doi.org/10.1177/0735633116667356

[33] H. Rahmayanti, I.Z. Ichsan, V. Oktaviani, Y. Syani, W. Hadi, G. Marhento, Environmental Attitude for Smart City Technology: Need Assessment to Develop Smart Trash in Environmental Education, International Journal of Advanced Science and Technology 29(3) (2020) 8374-8383.

[34] S. Ramadhan, D. Mardapi, Z.K. Prasetyo, H.B. Utomo, The Development of An Instrument to Measure The Higher Order Thinking Skill in Physics, European Journal of Educational Research 8(3) (2019) 743-751. DOI: https://doi.org/10.12973/eu-jer.8.3.743

[35] N. Sener, C. Turk, E. Tas, Improving Science Attitude and Creative Thinking through Science Education Project: A Design, Implementation and Assessment, Journal of Education and Training Studies 3(4) (2015) 57-67. DOI: https://doi.org/10.11114/jets.v3i4.771

[36] B.C. Herman, D.C. Owens, R.T. Oertli, L.A. Zangori, M.H. Newton, Exploring The Complexity of Students' Scientific Explanations and Associated Nature of Science Views Within A Place-Based Socio-scientific Issue Context, Sciences Education 28(3) (2019) 329-366. DOI:https://doi.org/10.1007/s11191-019-000344

[37] O. Derevenskaia, Active learning methods in environmental education of students, in: Procedia-Social and Behavioral Sciences, vol. 131, Elsevier, Amsterdam, 2014, pp. 101-104. DOI:

https://doi.org/10.1016/j.sbspro.2014.04.086.

[38] H. Ito, N. Kawazoe, Active Learning for Creating Innovators: Employability Skills Beyond 
Industrial Needs, International Journal of Higher Education 4(2) (2015) 81-91. DOI: https://doi.org/10.5430/ijhe.v4n2p81

[39] D.V. Sigit, M. Miarsyah, R. Komala, A. Suryanda, I.Z. Ichsan, R. Fadrikal, EECN: Analysis, Potency, Benefit for Students Knowledge and Attitude to Conserve Mangroves and Coral Reefs, International Journal of Instruction 13(1) (2020) 125-138. DOI: https://doi.org/10.29333/iji.2020.1318a

[40] M.H. Tsai, M.C. Wen, Y.L. Chang, S.C. Kang, Game-Based Education for Disaster Prevention, AI and Society 30(4) (2015) 463-475. DOI:https://doi.org/10.1007/s00146-014-0562-7

[41] N. Uzun, A sample of active learning application in science education: The thema "cell" with educational games, in: Procedia-Social and Behavioral Sciences, vol. 46, Elsevier, Amsterdam, 2012, pp. 2932-2936. DOI: https://doi.org/10.1016/j.sbspro.2012.05.592

[42] C. Hockings, L. Thomas, J. Ottaway, R. Jones, Independent Learning-What We Do When You're Not There, Teaching in Higher Education 23(2) (2018) 145-161. DOI: https://doi.org/10.1080/13562517.2017.1332031

[43] C. Kivunja, Teaching Students to Learn and to Work Well With $21^{\text {st }}$ Century Skills: Unpacking The Career and Life Skills Domain of The New Learning Paradigm, International Journal of Higher Education 4(1) (2015) 1-11. DOI: https://doi.org/10.5430/ijhe.v4n1p1

[44] J. Reyna, J. Hanham, P.C. Meier, A Framework for Digital Media Literacies for Teaching and Learning in Higher Education, E-Learning and Digital Media 15(4) (2019) 176-190. DOI:https://doi.org/10.1177/2042753018784952

[45] A.C. Saputri, S. Sajidan, Y. Rinanto, A. Afandi N.M. Prasetyanti, Improving Students' Critical Thinking Skills in Cell-Metabolism Learning Using Stimulating Higher Order Thinking Skills Model, International Journal of Instruction 12(1) (2019) 327-342. DOI: https://doi.org/10.29333/iji.2019.12122a

[46] M. Paristiowati, T. Hadinugrahaningsih, A. Purwanto, P.A. Karyadi, Analysis of students' scientific literacy in contextual-flipped classroom learning on acid-base topic, in: Journal of Physics
Conference Series, vol. 1156, IOP Publishing, Bristol, 2019, pp. 1-7. DOI: https://doi.org/10.1088/1742$\underline{6596 / 1156 / 1 / 012026}$

[47] H. Rahmayanti, S. Ananda, Analysis of Environmental Infrastructure Sustainability of Low Cost Apartment: Rusunawa in Jakarta, International Journal of Social Ecology and Sustainable Development 8(2) (2017) 1-13. DOI: https://doi.org/10.4018/IJSESD.2017040101

[48] M. Ertz, F. Karakas, E. Sarigöllü, Exploring ProEnvironmental Behaviors of Consumers: An Analysis of Contextual Factors, Attitude, and Behaviors, Journal of Business Research 69(10) (2016) 3971-3980. DOI: https://doi.org/10.1016/j.jbusres.2016.06.010

[49] V. Kartikaningtyas, T.A. Kusmayadi, R. Riyadi, The effect of brain based learning with contextual approach viewed from adversity quotient, in: Journal of Physics Conference Series, vol. 1022, IOP Publishing, Bristol, 2018, pp. 1-8. DOI: https://doi.org/10.1088/17426596/1022/1/012014

[50] D.V. Sigit, E.P. Azrai, E. Heryanti, I.Z. Ichsan, Y.P. Jajomi, R. Fadrikal, Development Green Consumerism E-Book for Undergraduate Students (Gc-Ebus) as Learning Media in Environmental Learning, Indian Journal of Public Health Research \& Development 10(8) (2019) 2026-2031. DOI: https://doi.org/10.5958/0976-5506.2019.02152.1

[51] M. Genc, T. Genc, P.G. Rasgele, Effects of Nature-Based Environmental Education on The Attitudes of 7th Grade Students towards The Environment and Living Organisms and Affective Tendency, International Research in Geographical and Environment 27(4) 2018 326340.

DOI: https://doi.org/10.1080/10382046.2017.1382211

[52] L.C. Garcia, Biology Education and Research in a Changing Planet, Springer, 2015.

[53] A. Harahap, A. Zuhriyah, H. Rahmayanti, N. Nadiroh, Relationship between knowledge of green product, social impact and perceived value with green purchase behavior, E3S Web of Conference, vol. 74, EDP Sciences Publishing, France, 2018, pp. 1-6. DOI: https://doi.org/10.1051/e3sconf/20187404002 